\section{Views from a Black Artist in the Century of Light}

\section{ELIZABETH DE SOUZA}

All artists, writers among them, have several stories - one might call them creation myths - that haunt and obsess them. This is one of mine. I don't even remember when I first heard about it. I feel I have always known it...

Edwidge Danticat, Create Dangerously 5

Twelve years ago, while planning the funeral service for my father, an artist and author born in Philadelphia in 1937, I found within the pages of one of his journals a phrase that caught my eye: The Sorrow Songs. Beneath it were the words Steal Away, which he'd underlined three times. I knew, of course, of the Negro Spirituals, and that this particular song was about the soul's flight to freedom, either with or without the body. Since that day, my mind often migrates back to those handwritten words, and sometimes I turn on Mahalia Jackson's peerless interpretation, and as her voice seeks heaven, I ponder the path bequeathed to me by my father.

From his earliest years, McCleary "Bunch" Washington, the great-grandson of a woman born into chattel slavery in South Carolina, kept a series of journals. He wrote in them daily. The surviving notebooks preserve in elegant calligraphy the candid thoughts of an erudite, deeply sensitive soul, keenly attuned to the tumultuous challenges of his era, ever willing to raise the call of the Beloved, and hoping the art he created would help bring forth gems of understanding that had been buried beneath centuries of bloodshed and ignorance.

$\mathrm{He}$ was a child of that bloodshed. But he escaped the home where dignity, humor, and spotless cleanliness lived alongside hidden abuse and humiliation. His first taste of freedom came early through the poetry he composed. Then he added color and canvas. By the time he arrived at Penn Station on a Greyhound bus with fifty dollars in the pocket of what he laughingly called his "civil rights jeans," he had studied at two prestigious art schools, agitated in the South as a member of SNCC, ${ }^{1}$ embraced a new Faith, opened and closed a small art gallery, and begun introducing himself by his unusual family nickname, Bunch, instead of his unusual first name, McCleary. It wasn't a total reinvention, but it was a start.

Bunch was a storyteller of the highest caliber. His embellishments were masterfully delivered with great comedic effect. The tricky part was that, since he was a certified trouble magnet, some of the stories that sounded like lies were entirely factual. It was the

1 The Student Nonviolent Coordinating Committee (SNCC, often pronounced "snick") was the primary avenue of civil rights activism for young Black people during the 1960s. 
ones that felt true that you had to look out for. He was one of those people who don't try to be unique - they just are.

In his work as a visual artist, he invented a polyester resin-based medium he called the "Transparent Collage." Like stained glass, the art relies on natural sunlight to illumine the colors and scenes that dance within. Resin is famously toxic and difficult to work with. Inhaling it can cause brain damage and worse. After masking himself and ensuring a ventilated space, Bunch mixed the poisonous liquid with a catalyst, then poured it into molds to which he dropped colored dye, objects, and drawings. After several days, the liquid solidified into a panel of art that he mounted on a wooden base and placed on a windowsill. Before discovering resin, Bunch's usual mediums were oil, collage, pen and ink, watercolor, sculpture, and bas-relief. His most consistent themes were family life, the arts, and the transcendent nature of the human soul. The Transparent Collage harmonizes these variated elements into a single genre that invariably expressed the same theme: unity.

Anyone who knew the tall, slender, dark-skinned, enigmatic painter knew he was a protégé of Romare Bearden, one of the greatest artists of the twentieth century, best known for his rich, complex, collaged scenes portraying archetypal aspects of African American culture. Most of them knew about the luxurious eight-pound coffee table volume, The Art of Romare Bearden: The Prevalence of Ritual, created by Bunch in 1972. His passion about this project that he called "more than just a book" was immense, and for good reason. It was the first major study of a Black artist in book form, and bringing it to fruition was about as easy as convincing water to flow upstream.

Since it was released when I was two years old, and the ripple effects generated by its critical acclaim dominated my childhood and beyond, I cannot remember a time I didn't have at least some understanding of why the fairskinned, soft-spoken man I called "Uncle Romy" (Row-me) was an important figure, not just for us Black folk, but for everyone, including those whose ancestors were on the other side of the whips and chains that are so inexplicably bound to America's mirage-like idea of a freedom. Today, nearly half a century after Bunch's book was released, his mentor's work is widely celebrated. Scholars have combed through the details of his life looking for any unexamined stone. Romy's own words - the books he wrote, the hundreds of interviews he granted-are abundant. And yet, in all of this, there are many stories that remain untold.

Here is just one: Romy had ties to the Bahá'í Faith that, to my knowledge, have never been publicly revealed or explored. It wasn't for lack of trying. I dare anyone who knew Bunch in life to ever suggest such a thing. It was because the person who was in the best position to illumine these ties also personified all that America has sacrificed to the "culture of contest" spoken of in Dr. Michael Karlberg's opening essay. It was because the person who 
tried for more than forty years to explain to his co-religionists of European descent why, why, why they should pay attention to a book that placed the work of the most impactful Black artist of the day alongside the mystic poetry of Bahá'u'lláh, and told the truth about the plague of racism while also praising Bearden's choice to "calm and educate" with his art-it was because the person saying all these things (and I heard him say them from the day I was born until the day he died) was himself a Black artist.

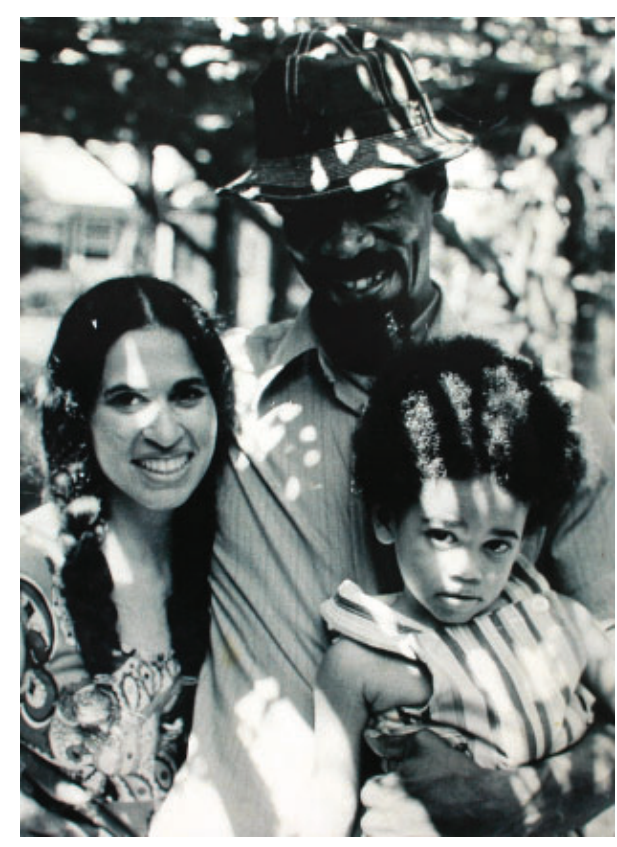

Bunch Washington, his wife Judith, and their son Jesse attend "Souvenir" at the Wilhelm Bahá'í properties in Teaneck,

New Jersey, circa 1972.

The annual gathering commemorates 'Abdu'l-Bahá's "Unity Feast" held in 1912 at the same location.

Photo credit: Al Burley.
Not only that, but he was six-footfive and darker than Africa and wore a beret on his nappy head and smoked a corncob pipe and it seemed to many of these White and Persian Bahá'ís that he was sometimes angry. Most of them hadn't yet had the experiences that would have allowed them to understand why they felt so uncomfortable in his presence, especially when he raised matters involving race and the American Bahá'í community. To them, it didn't feel like they were privileging their own inherited socio-political power over any gains that might come from making more of an effort to understand the message Bunch so urgently wished to deliver. Instead, they thought perhaps this quietly intense man needed to review Shoghi Effendi's words about achieving racial harmony: "Let the Negroes, through a corresponding effort on their part ..." (Advent 40).

Many Bahá'ís know this passage well. My mother is White; I have never not known it. I was born in 1970 and came of age during a time when interracial families, even within the Bahá'í Faith, and even within large U.S. cities, were rare. The Advent of Divine Justice, written by Shoghi Effendi, is an important and authoritative text for Bahá'ís. Among other things, it speaks explicitly about the "corrosion" of racial prejudice and calls upon all people to take full responsibility for its eradication (32). In part, it instructs White Bahá'ís to recognize their "usually inherent and at times subconscious sense of superiority" (40) and challenges Black Bahá'ís to respond with warmth 
while manifesting "their ability to wipe out every trace of suspicion that may still linger" within (40). This missive was originally released in 1938 as a letter to the Bahá'ís in the United States and Canada. It uses words like "Negro" and "colored" that have fallen out of use. The pointed analysis and directives it gives, however, are anything but dated. The words are true as the North Star, a light for those who seek guidance.

Yet and still, in some Bahá'í communities in the States, there is a proclivity to overcome points of disagreement by engaging in what Lloyd Lawrence, also a Black artist and a Bahá'í, calls "the quote wars." That is, using the sacred texts to shut down what could otherwise be a fruitful consultation. This I find depressingly hilarious. It reminds me of when my two young children argue over who gets to say their prayers first.

In Dawn Over Mount Hira, the prolific and poetic Marzieh Gail puts forth this observation:

The desire to be understood is common to us all. And yet no one understands us. We do not understand ourselves ... human beings are each on individual islands, shouting to each other across seas of misunderstandings. But prayer is the great simplifying factor and a dispeller of confusion. Through our communion with God we become explained to ourselves and enabled to express our best and truest selves to others. (28)
This is what Bunch's book on Romy was about. Rather than yelling across oceans, he looked within, prayerfully. His book is as much about him as it is about his mentor. He looked within as an artist. He looked within as a Black man. He looked within as a follower of Bahá'u'lláh. In these three intertwining identities we see the convergence of many complexities, many patterns. At the simplest level, we have three main strands: Artist. African American. Bahá'í.

Artists are famously misunderstood and Black people are persistently and even murderously misunderstood. The Bahá'í Faith has been attacked by its enemies with deadly intent from its inception until today. And why? It has something to do with a distorted perception of what power is, and how to get it. The most evolved artists are those whose work helps bring clarity, allowing us to reconnect with our inner truths. Black people in America know something about that mysterious power that comes from within-how else could we have continued to rise, despite wave after sickening wave of violent repression? The immortal words of Maya Angelou raise our eyes ever upwards:

You may shoot me with your words,

You may cut me with your eyes,

You may kill me with your hatefulness, But still, like air, I'll rise. 
These are words the Bahá'ís still undergoing persecution in Iran could have written. These are words that apply to every person on earth.

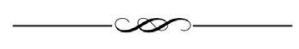

On the great plantations of the South, and in the shanties of mud and wood that lay on their perimeter, and in the smoky outdoor kitchens found behind the plantation house, and in the cotton-dotted fields, a glorious and peculiar sound could be heard - the music of an oppressed people worshipping God as they toiled. With a lifetime of unpaid labor stretching before and behind them, and amidst the cruelties and humiliations heaped upon them, there rose in their chests an expression of their inner reality: one that knew freedom. Bridging centuries and kingdoms, the cadences and cross-rhythms first formed in disparate places across Africa were overlaid in and through a European language. At the dawn of the twentieth century, the great sociologist, activist, and author W. E. B. Du Bois wrote about these songs in his seminal book The Souls of Black Folk, published in 1903. He wanted to debunk the myth, prevalent in film and theater as well as school textbooks, that the captives sang because they were happy. These songs, he said, were this country's first authentic folk music. Now, more than a century later, we understand that much of the music that uplifts and inspires us all originally sprang from those who were unimaginably downtrodden.

In 2016 the literary imagination of renowned poet Nikki Giovanni conjured up an old Black woman. Despite her age, she was captured and tethered to other people in the putrid underbelly of a slave ship. Her companions had different languages and customs, but all were miserable in the knowledge of their defeat. Says Giovanni:

She had to find a way to lift them together. The only thing she had was a moan. And she moaned. That moan would become a Spiritual; that Spiritual would become Jazz; which would become Blues then Rhythm and Blues then Rap. That moan would define not only a people but the nation to which they were sailing. That moan would make those people decide that they should, that they could, live. (xi)

With notes that now ring out from every part of the globe, these songs are constructive resilience in action. Never static, they respond fluidly to meet any environment. The same song is never the same, and why should it be? It is intuitive and improvisational; it asks and answers, affirms and refutes. Like life after death, a song's finale is sometimes transformed into a fresh beginning when the chorus is born again with a new, celebratory tempo. Pieces of one song jump into another; freshly composed verses are added and subtracted like mathematical poetry. Authorship is not singular, but plural - this is the African way. Joined in song, there is a state of unity in which things work 
together on their own. We are synced, you speak what I think. Perhaps this is what it means to "walk with the same feet" and "eat with the same mouth," as Bahá'u'lláh has spoken of in the Hidden Words (Arabic no. 68).

With this power, we become more than mere humans stuck within our oppressive conditions. We are active agents in our own liberation, making a way where once there was none. Steal away, the enslaved people sang to mourn a lost one, or to signal that the time had come to physically steal their own selves far, far away from those who claimed to own them. My Lord, He calls me, He calls me by the thunder / The trumpet sounds within my soul, I ain't got long to stay here... This is the sound of a people who have learned to locate their truest selves on that invisible map of the heart which Bahá'u'lláh has likened to a city: "Open, O people, the city of the human heart with the key of your utterance" (Gleanings 139:5). Soon I will be done with the troubles of this world . . . Mahalia Jackson's voice rises and falls like the hopes of those she descended from, reminding us how temporary this all is, all we can touch with our human hands. Ms. Jackson, whose father was born into slavery, is widely reported as having said that she sings "God's music because it makes me feel free. It gives me hope." I can't help wondering - how did these songs that began as a symphony of tears evolve into a messenger of hope and freedom?
Romy famously likened his art to jazz. He co-wrote a popular tune, "Seabreeze," recorded by jazz legend Dizzy Gillespie and the well-known vocalist and band leader Billy Eckstine. Part of what made Romy exceptional is that he found a potent visual language to express his love and admiration for the ordinary, oppressed Black people of the Americas. Because he saw their beauty, he was able to show it to other people, and most crucially, to Black people themselves.

This kind of work takes great sensitivity. If you're wondering if sensitivity is important, think about the human eye. We don't complain about protecting our eyes or giving them special consideration, we just do it. I've often wondered how this might relate to the "pupil of the eye" ("Abdu'l-Bahá, Selections ch.78) designation in the Bahá'i Writings that is explored by some of my colleagues in this issue. I wonder, in particular, how this relates to our Black artists. What do we stand to lose by not deliberately protecting them?

Romy knew that the creative well from which all artists draw is sensitive to impurities, and that his dark-skinned protégé attracted micro-aggressions like black wool picks up lint. He told Bunch that the answer to these troubles could be found in his work. In one letter, we hear Romy counseling the younger artist about a part of Bunch's life that seemed irresolvable:

When I spoke with you on the phone several months ago you 
were a bit upset with some of your Bha'i [sic] colleagues. That's all right, most of the very good artists had to keep on working, like Picasso and Matisse and Munch, to resolve in their art what they could not do in their lives ... I don't mean that as an escape from life except that "art" is another world that alludes to life.

It is both disappointing and illuminating that the astute pen of Romare Bearden, whose images chronicle Black tradition, also recorded evidence of Bunch's friction within his faith community. My father struggled with interpersonal relationships throughout his life. Generational racial trauma, a face and body that evoked fear, an uncompromising attitude towards his work, all of these contributed. Yet none of these other conflicts are mentioned in Romy's letters, only Bunch's trouble with some Bahá'ís.

Eventually, after a particularly disturbing dispute, Bunch officially withdrew his Bahá'í membership. I was ten years old at the time. The impact this had on my family cannot be overstated.

McCleary Washington was born in the month of Beauty. ${ }^{2}$ He most often referred to Bahá'u'lláh by the title "The Blessed Beauty." ${ }^{3} \mathrm{He}$ spent forty

2 Bahá'ís follow a solar calendar divided into nineteen months. Each month is named after an attribute of God, such as Glory, Power, Loftiness, etc. Washington's birthday falls in the month of Jamál, an Arabic word for beauty.

3 One of His many titles widely years turning a poisonous substance into a new form of beauty. Though he'd seen more ugliness in his life than most, his work radiates tranquility. He'd enrolled in the Faith as a young man in Philadelphia. His belief was a flame that spread across cultural lines, eventually enkindling his Jewish-born wife and her mother, and also Bunch's younger brother. Even his grandmother, a devout Baptist, signed a Bahá'í declaration card, citing Biblical prophesies about "twin lights" as her confirmation. For Bunch, exiling himself from the circle of believers plunged him into an ancient well of spiritual anguish that touched everything he did thereafter.

And yet he continued to create. Romy's advice allows us to see that Bunch did, in fact, resolve in his art what he could not in his life. In his Transparent Collage, the same sensitivity that caused him so much anguish is the very feature that makes his medium captivating. The swirling colors in these works shift and change with every fluctuation of the sunlight that illumines them. Like the Sorrow Songs, they are never static. In fact, when the light is low, the artwork takes on a special glow, seemingly lit from within, reminding us of how even the smallest degree of light can be transformative. In these works, Bunch has finally harmonized the three main elements in his life: Artist, African American, Bahá'í. What is left of his struggle is not a catalogue of pain, but mesmerizing portraits of light. Part poetry, part prayer,

known among Bahá'ís. 
they are constructive resilience made tangible.

Another hidden gem that Bunch's work brings forth can be found in a small brochure for an even smaller exhibition of his Transparent Collage held on Long Island in 1975. In it, Romy writes:

Some of the symbols that Washington uses relate to his study of Persian Arts and his dedication to the Bahá'í Faith, a religious system founded in Persia by Bahá'u'lláh, that teaches the unity of all religions and the over-riding duty of the Bahá'is to serve the needs of mankind. The word "symbol" is stressed because the Bahá'ís are carefully enjoined not to use certain likenesses of their Founders, nor too literal interpretations of their concepts. It is interesting, therefore, that this artist, who uses some of the most modern methods, should at the same time concern himself with such ancient values; however, Washington's concepts are seldom superimposed upon his material, rather he actually creates with them. (Bearden, Transparent Collages)

People interested in art, history, and the Bahá'í Faith might wonder why they never came across this reflection from Bearden about the Greatest Name ${ }^{4}$ as

4 The Greatest Name is an Arabic calligraphic symbol for the invocation "Yá Bahá'u'l-Abhá," or in English, "O Glory of the All Glorious." Bahá'ís believe that it appears in Bunch's art. Few will understand the role that racism played in hiding these words from sight, just as Bunch eventually hid himself from those he most wished to be amongst.

A handful of people do understand. One of them is Dr. William Roberts, who knew Bunch for close to thirty years. Like Bunch, "Billy," as his friends call him, is African American and stands well over six feet tall. He is also a clinical psychologist who served for more than a decade on the National Spiritual Assembly of the United States. ${ }^{5}$ In 1987, Dr. Roberts launched an independent initiative that provided a space for Black men to empower and uplift each other while seeking a more active role within the Bahá'í framework for action. Sanctioned by the Universal House of Justice, the Black Men's Gathering continued for twenty-five years, profoundly impacting lives and enriching the devotional character of Bahá'í communities worldwide (see Landry, McMurray, and Thomas).

In an interview that took place six years after Bunch's death, Billy commented on how racial stereotyping prevented many people from seeing in Bunch what was obvious to him:

Simply being Black and male in America ... his intensity was often

"Bahá," or "Glory," is the greatest name of God, alluded to by past religions, but not revealed until the advent of the Bahá'í Faith.

5 An elected council of nine people that guides the affairs of the American Bahá'í community. 
misunderstood for aggression and hostility ... He was a person who walked the path of a visionary. He always saw the beauty in others, even those with whom he disagreed. He was a humble individual and he was also a promoter of justice. . . . And then of course there's his championing of Romare Bearden, and other artists . . . It's a good example of somebody who people want to call angry, but you know, angry people don't champion other people. If you're really angry, there's no space in you to honor others, to love others, to appreciate others, to value others, to pay tribute to others. Bunch was all about that.

Dr. Roberts also remarked upon Bunch's intense and "very determined" nature. Indeed, relinquishing his Bahá'í membership never stopped my father's efforts to share the Faith. Here is just one example: Romy and his wife Nanette kept a home on the Caribbean island of Martinique. For years, Bunch urged Romy to connect with a White Bahá'í named Barbara Joyce, also a painter who lived on the island. After many reminders from Bunch, the busy, famous, elderly artist finally sought her out. She in turn introduced Romy to a Bahá'í named Shamsi Sedaghat.

To be clear, Romy knew quite a bit about the Faith already. He was the one who'd first told Bunch that writer and critic Alain LeRoy Locke, often called the Father of the Harlem Renaissance, ${ }^{6}$ was a Bahá'í. But something about this "Persian lady" who ran a maternity clinic in majority-Black Trinidad was different. Romy wrote to Bunch:
After [reading Paris Talks], I felt that this Faith is one that can only be truly understood by service- by devotion to "good works." As I could see all the fervor and ded- ication, and love of what she was doing, on the Persian woman's face. She has a quality-a pres- ence... The Persian lady said that one day I would become a B'haist [sic] as she saw it in my face but I told her I doubted that, at least not officially.

If you knew Romy, "not officially" was jaw-dropping. Among other things, it highlights what Hand of the Cause ${ }^{7}$ Rúhíyyih Khánum once explained:

6 The Harlem Renaissance (19181937) was a cultural outpouring from African American artists, musicians, writers, and scholars, also called the New Negro Movement, concentrated in but not confined to the Harlem district of New York City.

7 Hand of the Cause of God was a lifetime appointed position bestowed upon a small, select group of Bahá'ís by either Bahá'u'lláh, 'Abdu'l-Bahá, or Shoghi Effendi. This institution has since been replaced with the Continental Board of Counsellors (established in 1968). The purpose of the Hands of the Cause was to propagate and protect the Bahá'í Faith on an international level. 
even people who agree with Bahá'ís on racial unity won't be moved until they see us all lovingly working together (Rabbani 2). Among the Bearden-Washington letters, this one alone is written on colorful, distinctive stationery by German artist Peter Max, investing it with another layer of singularity. After Romy's death in 1988, the letter became even more precious to the man who himself was "not officially" a member of the Faith he cherished.

In 1961, Rúhíyyih Khánum wrote to the National Spiritual Assemblies of Canada and the United States about her recent journey through East Africa. She spoke of how her experiences there had changed her perspective so completely that, in her words, she "[felt] as if [she] was living in a different mental world from before" (Rabbani 1). This trip took place after the death of her beloved husband, Shoghi Effendi. After spending weeks on end in close contact with hundreds of Africans, she reflected upon the qualities they had in common with their African American brethren. What struck her most, she said, was "the spiritual quality defined as 'heart' in our teachings" (2). She called attention to how this word appears in the Writings, for example, "'Thy heart is My habitation,' and 'My first council is this: Possess a pure, kindly, and radiant heart"' (2).

Reading this, I thought of how my father referenced the Hidden Words in his book, saying that Romy had a heart such as it described. He identified this quality as the origin of Romy's strength and power.

Before her travels to Africa, Rúhíyyih Khánum had never considered that this same quality might be common as a copper penny among Black and Indigenous people worldwide. Finally, she understood why Shoghi Effendi constantly mentioned "the 'pure-hearted' African" (Rabbani 2). She also warned that "[w]e must guard ourselves against the dry and dead intellectualism of the world in which we live!" Even on the printed page, her fervor and conviction are palpable:

The people of the world are tired of words, words, words. They don't really pay any attention to what we say about "oneness, unity, world brotherhood" although many of them agree with this. What they need is to see deeds, to see Bahá'í communities, local and national, full of people of different races working together, in love, for their common belief. Then the spiritual force such a reality will release (as opposed to words) will bring an inwardly hungry, sad and disillusioned white race into the Faith in larger numbers. It is all there in the writings of Shoghi Effendi; we just don't think about it enough. (2-3)

I once shared this letter with a Bahá'í of African descent who is a gifted vocalist. Earlier that day, she had spoken to me about her immense love for Bahá'u'lláh and His Revelation, and 
also about the believers in her community, whom she considered family. Later, when she opened up about some of the troubles she'd had with them, I found the letter, printed it, and watched her read it. My ears have still not recovered from both the volume and the emotion in her voice as Rúhíyyih Khánum's words permeated her spirit. At one point, she threw back her head and hollered with relief and validation. Tears sprang into her eyes and she dropped her head into her hands and wept.

She loved her community, she'd told me earlier, and they loved her, too. But she could no longer endure how their unconscious anti-Blackness affected her mental wellbeing. Too often, she returned home from Feast feeling misunderstood and disrespected. When she finally confessed her feelings to her Bahá'í family, what she received in response was an email containing the words of Shoghi Effendi: "Let the Negroes, through a corresponding effort on their part . . ." (Advent). It was hurtful beyond words. What this woman needed at this moment was not a quote about how she could be a better Bahá'í. What she needed, at a minimum, was to be heard.

This is the sorrow song of the African American believer, and it has been sung since the days of Hand of the Cause Louis Gregory-a contemporary of W. E. B. Du Bois - of whom 'Abdu'l-Bahá once said, "That pure soul has a heart like unto transparent water. He is like unto pure gold" (qtd. in Morrison 314).
While on pilgrimage in 2011, I found myself sitting on a charter bus next to an elegant, slender, sprightly White woman of my father's generation. As our bus approached 'Abdu'l-Bahá's house in 'Akka, she questioned me about my life the way friendly people often do, except she listened, really listened, to my responses. I was moved by her interest. It said more about her than it did about me. Who was she? Where was she from? She answered thoughtfully, always managing to steer the conversation back to me. When she learned I was in graduate school writing a book about my late father, who'd contributed much to the world in spite of a mental health crisis and drug addiction that rendered him homeless in the last few years of his life, she pulled out a notebook and asked me how to spell his name. As I did, her eyes widened in shock and her pen became still.

"McCleary? McCleary from Philadelphia is your father?" Her eyes filled with tears. She looked at me searching1y. "I knew McCleary, years and years ago. Such a remarkable person, so full of life and joy, such a powerful and inspiring presence." She blotted her eyes and told me she'd thought of him over the years, wondering what became of the magnetic young man with the "strong spirit." Then she said something even more surprising. "I had no idea he was an artist. I knew him as a poet."

In the days we spent together, her modesty and humility came into fuller 
view. I was surprised and not surprised to discover that in her youth, she had spent time with Rúhíyyih Khánum for a project at the Bahá'í World Centre. When I told her that as a child in New York City, I'd presented Rúhíyyih Khánum with a bouquet of roses, her smile was sunlight itself. Was my father there? Yes, I told her, along with my whole family. She nodded once, then twice, as if I'd confirmed some great truth.
After returning home, my mother squealed when I asked if she remembered the name Ellen Parmalee. "Do I remember? She taught your father the Faith!" And then I recalled Dad laughing about a young lady he'd initially hoped to date, except she was "far too pure" to be interested in him that way. Mom and I marveled that out of some three hundred pilgrims, Mrs. Parmalee and I landed in the same group, on the same bus, sitting together on that first

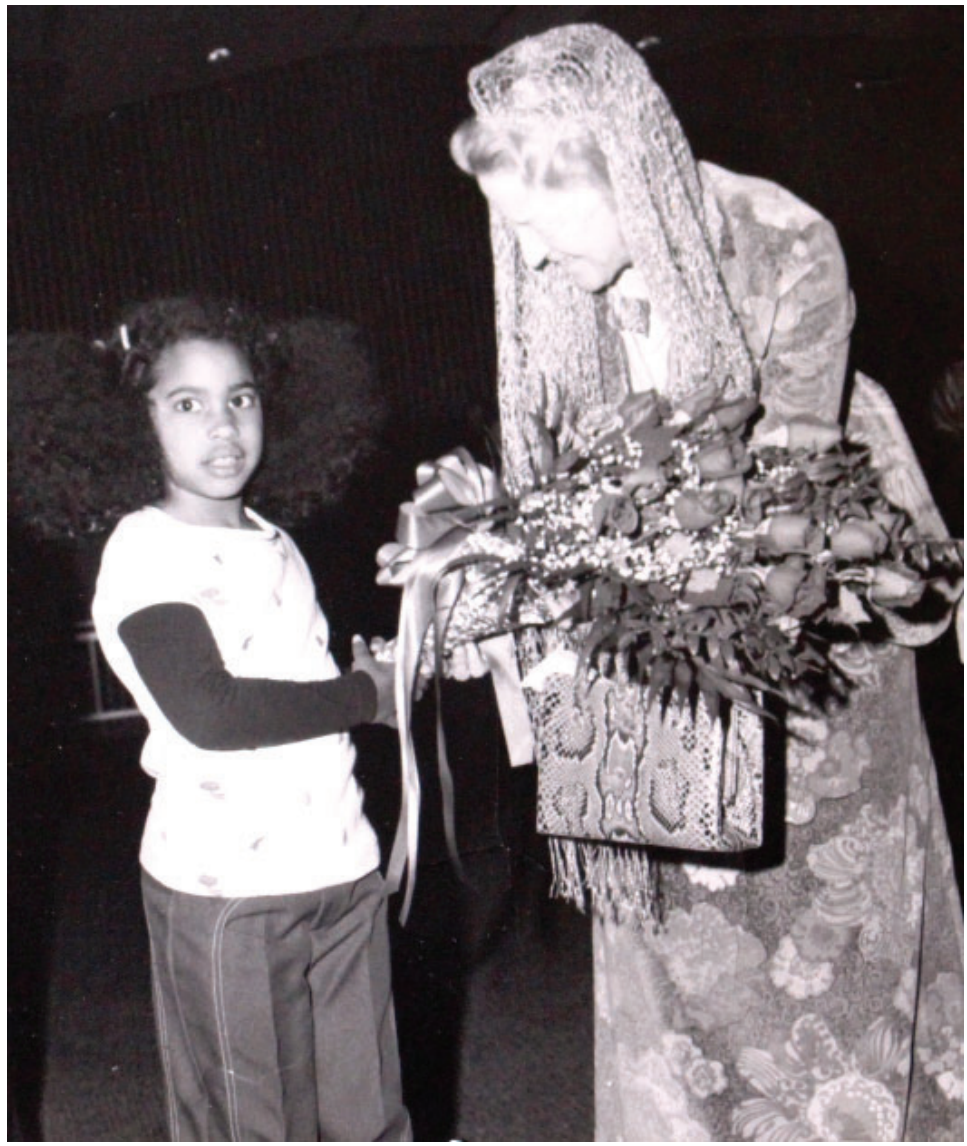

The author presents Hand of the Cause of God Rúhíyyih Khánum with roses at the New York City Bahá'í Center, circa 1977, after a screening of the film Green Light Expedition. 
approach to 'Abdu'l-Bahá's house. Even more astonishing: my original pilgrimage date, months earlier, had been a failure. On the big day, I lost my passport at the airport somewhere between the TSA checkpoint and the departing gate. It was one of my most miserable moments on planet Earth. And yet, had I been spared that agony, I wouldn't have felt the sweetness of walking in the footsteps of the Holy Ones with my spiritual grandmother.

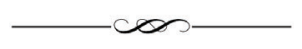

About seven years before his Lord called him home, my father urged me to read the newly released Century of Light, wherein the House of Justice turns its infallible pen to world events of the past century and their relationship to the emergence of the Faith. I knew the title held significance for him. Many times, I'd heard him say, "The Master has said we are living in the 'century of light,' and therefore, I wish to paint with light..."

I don't know exactly what section of this book provided him with the explanation he so needed about his estrangement from the Bahá'i community, and also about his relationship to the institutions of the Faith that had failed to swoop into his interpersonal conflicts and deliver immediate and unquestionable justice in all the ways he wished. However, after reading this book, Bunch re-enrolled himself in the Faith after an absence of twenty long years. Come what may, he was a Bahá'í, and he wasn't going to let "nobody turn him 'round," as the old song goes. Certainly not when the adversarial forces came from the world, but also from within. Years later, I would understand that while Bunch was unique, his struggle as a Black Bahá'í in America was not. But neither was the imperishable bond of genuine love and friendship, unsullied by racial prejudice, that many of his Bahá'í brethren and sistren of all races shared with him over the years. This is the love that shines indiscriminately upon all who turn their faces towards its warmth. Now, each time I pick up Century of Light, I hear the songs of our ancestors, never static, rising and swelling, their truth and simplicity carrying us forward as we work together for our promised liberation.

\section{Works Cited}

'Abdu'l-Bahá. Selections from the Writings of 'Abdu'l-Bahá. Bahá'í World Centre, 1982.

Angelou, Maya. And Still I Rise: A Book of Poems. Random House, 1978.

Bahá'u'lláh. Gleanings from the Writings of Bahá u'lláh. U.S. Bahá'í Publishing Trust, 1990.

___ The Hidden Words. U.S. Bahá'í Publishing Trust, 2001.

Bearden, Romare. Transparent Collages: Views from a New World Order, or Light. The Off Broadway Gallery, 1975.

Letter to McCleary Bunch Washington, circa 1985-87, McCleary Bunch Washington papers, National Bahá'í Archives, United States. 
Danticat, Edwidge. Create Dangerously: The Immigrant Artist at Work. Princeton UP, 2010.

Du Bois, W. E. B. The Souls of Black Folk. A. C. McClurg \& Co., 1903.

Gail, Marzieh. Dawn Over Mount Hira and Other Essays. George Ronald, 1976.

Giovanni, Nikki. Foreword. Jubilee, by Margaret Walker Alexander, Houghton Mifflin Harcourt, 2016. pp. x-xi.

Landry, Frederick, Harvey McMurray, and Richard W. Thomas. The Story of the Bahá'i Black Men's Gathering: Celebrating Twenty-Five Years, 19872011. U.S. Bahá'i Publishing Trust, 2011.

Morrison, Gayle. To Move the World: Louis G. Gregory and the Advancement of Racial Unity in America. U.S. Bahá'í Publishing Trust, 1995.

Rabbani, Rúhíyyih Khánum. "Ruhiyyih Khanum Shares Teaching Observations." Bahá'i News: U.S. Supplement, no. 40, June 1961, pp. 1-4.

Roberts, William. Interview with Brianna Robinson. 2014. Sleeping in the Fire, bunchwashington.com/memories-of-bunch.html.

Shoghi Effendi. The Advent of Divine Justice. U.S. Bahá'í Publishing Trust, 1938. Washington, M. Bunch. The Art of Romare Bearden: The Prevalence of Ritual. Abrams, 1973.

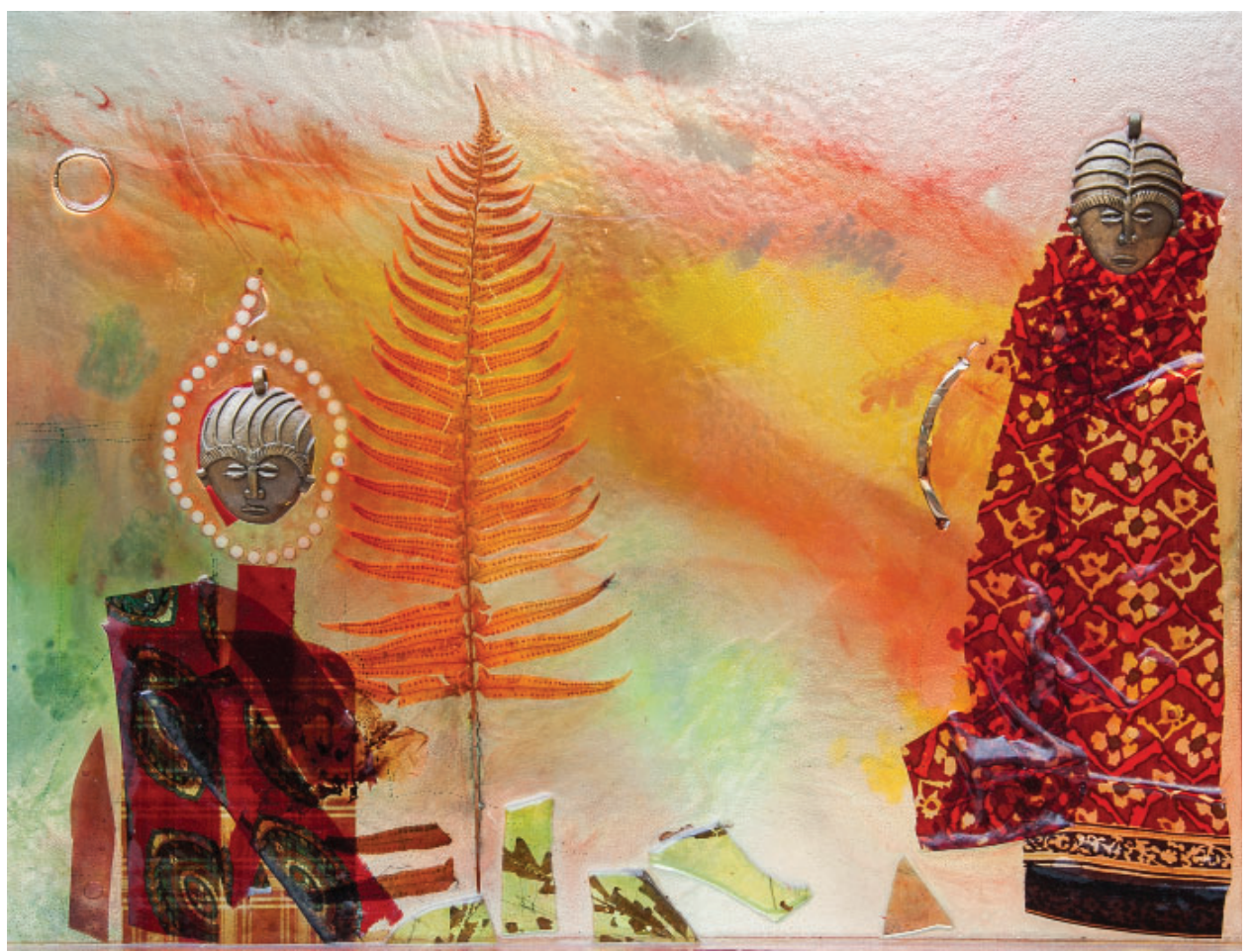

Pearls

M. BUNCH WASHINGTON 